\title{
A beállítási biztonsági margó nagyságának meghatározása fej-nyak daganatok 2D-2D és 3D képvezérelt intenzitásmodulált sugárkezelése esetén
}

\author{
Kovács Péter dr. ${ }^{1,2}$ - Szita Evelin ${ }^{1}$. Schvarcz Kitti ${ }^{1}$ \\ Kamu Szabolcs ${ }^{1}$. Kalincsák Judit dr. ${ }^{2}$ - Kovács Árpád dr. ${ }^{1,3}$ \\ Repa Imre dr. ${ }^{2,3}$ - Hadjiev Janaki dr. ${ }^{2}$

\begin{abstract}
${ }^{1}$ Pécsi Tudományegyetem, Egészségtudományi Kar, Képalkotó Diagnosztikai Tanszék, Kaposvár ${ }^{2}$ Somogy Megyei Kaposi Mór Oktató Kórház, Dr. Baka József Diagnosztikai, Onkoradiológiai, Kutatási és Oktatási Központ, Kaposvár
\end{abstract} \\ ${ }^{3}$ Pécsi Tudományegyetem, Egészségtudományi Kar, Egészségtudományi Doktori Iskola, Pécs
}

\begin{abstract}
Bevezetés: A fej-nyak daganatok képvezérelt intenzitásmodulált sugárterápiája a komplex onkológiai ellátás része. Célkitüzés: Összehasonlítottuk a fej-nyak tumoros betegek IGRT-besugárzása során a MV-kV és a CBCT képalkotó modalitásokat. Vizsgáltuk a beállítási hibát, a mozgási biztonsági margót (SM), a képalkotási és a hibameghatározási időt, a képalkotási dózisokat.

Módszer: Nyolc beteg elektív kezelését vizsgáltuk, 66 kétirányú MV-kV felvételt és 66 CBCT-felvételt készítettünk. Három transzlációs irányban csontalapú manuális regisztrációval meghatároztuk a beállítási hibát. Az összehasonlítást normalitásvizsgálatot és F-próbát követően kétmintás T-próbával végeztük. Van Herk képlete alapján kiszámítottuk az alkalmazandó beállítási biztonsági margót. Megmértük a képalkotáshoz és a beállítási hiba meghatározásához szükséges időket. Szakirodalmi adatok alapján becsültük a képalkotási dózisokat.

Eredmények: Statisztikailag szignifikáns eltérést a MV-kV és a CBCT által adott beállításihiba-eredmények között nem találtunk (VRT: $0,5 \mathrm{~mm}, \mathrm{SD}=1,9$ vs. $0,4 \mathrm{~mm}, \mathrm{SD}=2,1, \mathrm{p}=0,371$; LNG: $0,2 \mathrm{~mm}, \mathrm{SD}=2,2$ vs. $-0,1 \mathrm{~mm}, \mathrm{SD}=$ $2,2, \mathrm{p}=0,188$; LAT: $0,2 \mathrm{~mm}, \mathrm{SD}=2,2$ vs. $0,3 \mathrm{~mm}, \mathrm{SD}=2,1, \mathrm{p}=0,41)$. Az SM-ek: VRT: $2,7 \mathrm{~mm}$ vs. $2,5 \mathrm{~mm}$; LNG: $2,1 \mathrm{~mm}$ vs. 1,3 mm; LAT: $2,2 \mathrm{~mm}$ vs. $2,3 \mathrm{~mm}$. A képalkotási idók átlagosan 0,65 perc $(\mathrm{MV}-\mathrm{kV})$ vs. 2,29 perc (CBCT). A beállítási hiba meghatározásának ideje mindkét képalkotónál átlagosan 2,41 perc. A becsült képalkotási dózisok frakciónként 6,88 mGy (MV-kV) vs. 17,2 mGy (CBCT).

Következtetés: Fej-nyak daganatos betegeknél csontregisztrációt használva a transzlációs hibameghatározás MV-kV és CBCT alapján hasonló eredményre vezet. $3 \mathrm{~mm}$ beállítási margó használata minden irányban kielégítő. A képalkotási idő MV-kV esetén alacsonyabb, a dózisban nincs jelentős különbség. Általánosan a CBCT használata javasolt. A MV-kV akkor jelent alternatívát, ha a képalkotási idő rövidítése szükséges.

Orv Hetil. 2018; 156(29): 1193-1200.
\end{abstract}

Kulcsszavak: biztonsági margó, IGRT, VMAT, fej-nyak

Setup margin for head-and-neck cancer patients receiving 2D-2D and $3 \mathrm{D}$ image-guided intensity-modulated radiation therapy

Introduction: Image-guided intensity-modulated radiation therapy is essential for oncology treatment of head-andneck cancer patients.

Aim: MV-kV and CBCT modalities were compared in case of IGRT treatment for head-and-neck cancer patients. Setup error, setup margin (SM), imaging and evaluation times and imaging doses were analyzed.

Method: Eight patients' elective treatment was evaluated, 66 orthogonal MV-kV images and 66 CBCT series were acquired. Setup error measurement was based on bony manual image registration in three translational directions. Normality test and F-test were performed followed by the comparison with independent-samples T-test $(\mathrm{p}<0,05)$. 
The necessary target volume setup margin was calculated based on Van Herk's equation. Imaging time and setup error determination time were measured. Imaging doses were estimated based on the literature.

Results: No statistically significant difference was found between setup errors determined by MV-kV and CBCT (VRT: $0.5 \mathrm{~mm}, \mathrm{SD}=1.9$ vs. $0.4 \mathrm{~mm}, \mathrm{SD}=2.1, \mathrm{p}=0.371 ; \mathrm{LNG}: 0.2 \mathrm{~mm}, \mathrm{SD}=2.2$ vs. $-0.1 \mathrm{~mm}, \mathrm{SD}=2.2, \mathrm{p}=$ 0.188 ; LAT: $0.2 \mathrm{~mm}, \mathrm{SD}=2.2$ vs. $0.3 \mathrm{~mm}, \mathrm{SD}=2.1, \mathrm{p}=0.4 \mathrm{l})$. SM values were: VRT: $2.7 \mathrm{~mm}$ vs. $2.5 \mathrm{~mm}$; LNG: $2.1 \mathrm{~mm}$ vs. $1.3 \mathrm{~mm}$; LAT: $2.2 \mathrm{~mm}$ vs. $2.3 \mathrm{~mm}$. Mean imaging time was $0.65 \mathrm{~min}(\mathrm{MV}-\mathrm{kV})$ vs. $2.29 \mathrm{~min}$ (CBCT). Mean setup error determination time was $2.41 \mathrm{~min}$ for both modalities. Estimated imaging doses were $6.88 \mathrm{mGy}$ (MV-kV) vs. 17.2 mGy (CBCT) per fraction.

Conclusion: The bony anatomy derived image registration based translational setup error determination results in similar values either by MV-kV or by CBCT. Using $3 \mathrm{~mm}$ setup margin in all the directions might be adequate. Imaging time is less by $\mathrm{MV}-\mathrm{kV}$, significant difference in imaging doses did not appear. Using CBCT is generally suggested. MV-kV might be an alternative in case of need for shortened imaging time.

Keywords: setup margin, IGRT, VMAT, head-and-neck

Kovács P, Szita E, Schvarcz K, Kamu Sz, Kalincsák J, Kovács Á, Repa I, Hadjiev J. [Setup margin for head-and-neck cancer patients receiving 2D-2D and 3D image-guided intensity-modulated radiation therapy]. Orv Hetil. 2018; 159(29): 1193-1200.

(Beérkezett: 2018. február 16.; elfogadva: 2018. március 20.)

\begin{abstract}
Rövidítések
CBCT $=($ cone-beam computed tomography) kúpsugaras számítógépes tomográfia; $\mathrm{CTV}=($ clinical target volume $)$ klinikai céltérfogat; DRR $=($ digitally reconstructed radiograph $)$ digitálisan rekonstruált röntgenkép; EPID = (electronic portal imaging device) elektronikus portálkép-felvételező eszköz; GTV = (gross tumor volume) makroszkópos céltérfogat; IGRT = (image-guided radiation therapy) képvezérelt sugárterápia; IM = (internal margin) szervmozgási biztonsági margó; IMRT $=$ (intensity-modulated radiotherapy) intenzitásmodulált sugárterápia; LAT = laterális; $\mathrm{LNG}=$ longitudinális; $\mathrm{MRI}=$ (magnetic resonance imaging) mágneses rezonanciás képalkotás; $\mathrm{MU}=$ (monitor unit) monitoregység; $\mathrm{PET}=$ (positron emission tomography) pozitronemissziós tomográfia; PTV = (planning target volume) tervezéses céltérfogat; $\mathrm{SM}=$ (setup margin) beállítási biztonsági margó; VMAT $=$ (volumetric modulated arc therapy) intenzitásmodulált ívterápia; VRT = vertikális
\end{abstract}

A Nemzeti Rákregiszter adatai alapján 2001 és 2014 között a rosszindulatú daganatos megbetegedések 6,55,1\%-át fej-nyaki lokalizációban diagnosztizálták [1]. Bár ez az arány az évek múlásával javuló tendenciát mutatott, a százezer före vetített fej-nyak tumorok száma nem változott jelentősen, 48 és 52 között ingadozott.

A fej-nyaki daganatok kezelése multidiszciplináris feladat, melyben a betegség stádiumától függően a sebészi beavatkozáson felül fontos szerepet játszik a gyógyszeres onkológiai ellátás, valamint a sugárterápia. E két utóbbi terápiás modalitást a gyakran szimultán kemoradioterápia formájában alkalmazzuk [2-4]. A sugárkezelés előkészítésének fontos lépése a céltérfogatok pontos meghatározása. A makroszkópos céltérfogat (GTV) kiterjedésének definiálása a képalkotó modalitások $(\mathrm{CT}$, MRI, PET) széles tárházának segítségével lehetséges
[5]. A morfológiai és funkcionális képalkotáson alapuló GTV-meghatározást követően fontos ismerni a betegség mikroszkópos és lokoregionális kiterjedését (CTVmeghatározás). A besugárzás tervezéséhez és a sugárkezelés hatékonyságának biztosításához szükséges a szervmozgások és a betegpozicionálási hibák figyelembevétele. Ezt biztonsági margók (IM, SM) alkalmazásával tehetjük meg [6].

Az IM használata a tüdődaganatok légvétel hatására bekövetkező, periodikus mozgásának figyelembevételéhez hasznos. A fej-nyaki besugárzási régióban a daganat elmozdulását lehetővé tevő belső szervmozgások hatása elhanyagolható, így az IM-meghatározás itt nem jelentôs szempont. Ezzel szemben a tervezéses céltérfogat (PTV) meghatározásakor alkalmazott beállítási biztonsági margó (SM) meghatározása és lehetséges csökkentése fontos. A szükséges legkisebb SM alkalmazása módot ad a védendő szervek és az ép szövetek dózisterhelésének csökkentésére, ezáltal a mellékhatások mérséklésére. E cél megvalósításának eszköze a modern sugárterápiás kezeléshez szorosan kapcsolódó képvezérelt sugárterápia (IGRT), melynek elsődleges feladata a beteg pontos pozicionálásának elősegítése. A pontos célzás alkalmazása biztonságot ad a PTV és a kritikus szervek között nagy dózisgradienst előállító besugárzási tervek (IMRT, VMAT) pontos leadásához is. Lehetővé válik a dóziseszkaláció, mely javíthatja a lokális kontrollt, vagy rövidítheti a kezelési időt [7].

A fej-nyaki daganatos betegek képvezérelt sugárkezelése esetén szükség van tehát a napi beállítási hiba mértékének megállapítására és korrekciójára. Ez a gyakorlatban történhet kétdimenziós ortogonális röntgenfelvételpárral $(\mathrm{MV}-\mathrm{kV})$ vagy cone-beam CT-vel (CBCT) végzett felvételezés alapján. Célunk volt megállapítani, hogy a betegpozicionálást és a célzást tekintve van-e lényeges 


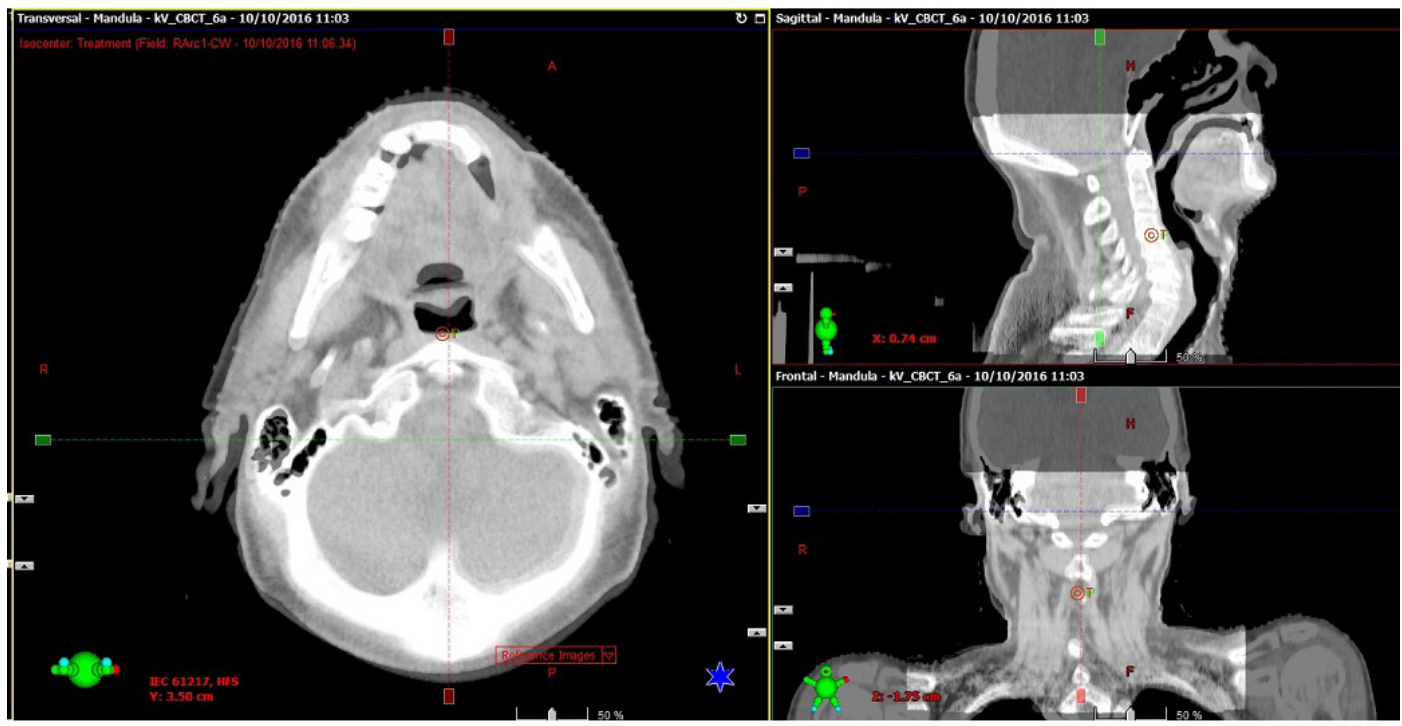

1. ábra

| DRR-ek ortogonális MV-kV felvételhez
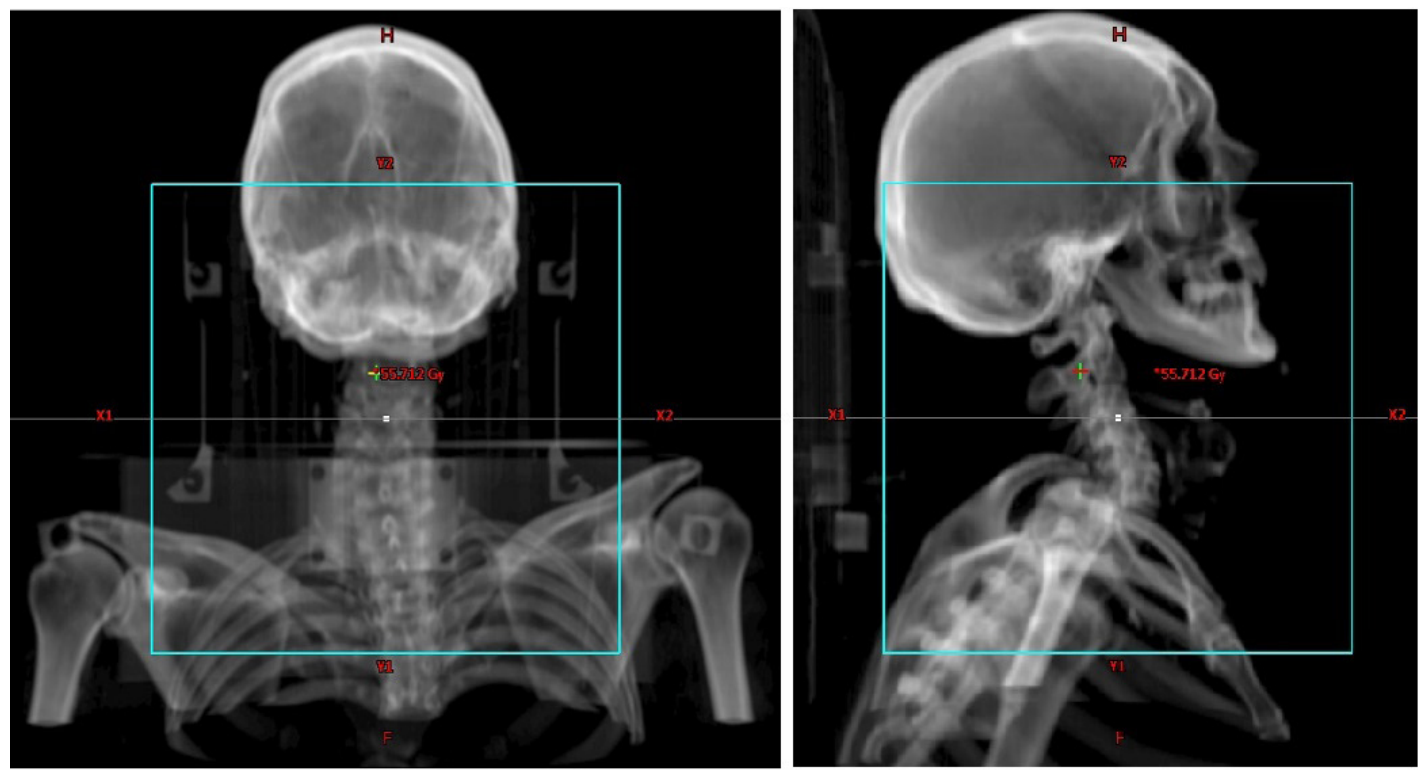

2. ábra

| CBCT és tervezéses CT fúziója

különbség a kétirányú 2D felvételek és a CBCT által szolgáltatott képi információból számított fektetési hibákban. Meg kívántuk határozni a szisztematikus és a véletlenszerü beállítási hibák mértékét, valamint az ezekből számítható, szükséges SM nagyságát. Össze kívántuk vetni az egyes modalitások által szolgáltatott felvételek elkészítéséhez szükséges időket és a képalkotás során a betegeket ért dózismennyiségeket is.

\section{Módszer}

A Somogy Megyei Kaposi Mór Oktató Kórház Dr. Baka József Diagnosztikai, Onkoradiológiai, Kutatási és Oktatási Központjában 2016. december és 2017. március között összesen 8 , fej-nyak daganatos beteg elektív mező- jénél végeztünk retrospektív vizsgálatot. A primer tumor lokalizációja nyelvcsúcsi (1), garati (1), gégei (2), szájfenéki (2) és nyaki nyirokcsomóáttét (1) volt. Célunk az SM minél pontosabb meghatározása volt, ezért a vizsgálatba olyan betegeket vontunk be, akiknek a kezelése során online IGRT-protokollt alkalmaztunk. A napi felvételkészítés tette lehetővé, hogy a beállítási hibát a teljes kezelési ciklus alatt, minden nap meghatározzuk. A kapott napi hibainformációt a fektetési pozíció korrigálására is felhasználtuk.

Kizárási kritérium volt, ha a két képalkotó modalitás közül csak az egyikkel készült felvétel, illetve ha az adott beteg nem vett részt legalább 30 alkalommal sugárkezelésen. Ezt ugyancsak a pontos, következetes és nagyszámú mérés igénye indokolta. 
A kezelések előkészítése során ötpontos, a koponyát és a vállakat rögzítő termoplasztikus maszkot, fejtartó párnát és indexált kezelőasztalt használtunk. A besugárzás tervezéséhez, valamint a referenciapozíció definiálásához natív tervezéses CT-vizsgálatot végeztünk. A betegek kezeléséhez intenzitásmodulált ívterápiás (VMAT) terveket készítettünk. A kezelések során, a lézeres betegpozicionálást követően, közvetlenül a terápiás besugárzás előtt készítettük a pozíció-ellenőrző felvételeket. Összesen 66 ortogonális MV-kV kép és 66 CBCT-felvétel készült. Minden betegnél naponta váltottuk az alkalmazott képalkotó modalitást. Csontalapú manuális regisztrációval három transzlációs irányban meghatároztuk a beállítási hibát, és kiszámítottuk a vektoriális eltérést. A primer tumorok fent említett lokalizációját figyelembe véve a csontalapú regisztráción felül a napi rutinban a lágyszöveti összevetést is hasznos lehet elvégezni, ám kiindulási alapnak a gerincvelő védelmének biztosítása érdekében a nyaki gerinc illesztését választottuk. Az egyes képalkotó eljárások által szolgáltatott eltolási értékeket utólagos adatelemzéssel hasonlítottuk össze, megállapítottuk a különbséget. Van Herk képlete alapján számítottuk ki a céltérfogat-definiáláskor használandó beállítási biztonsági margó nagyságát [8]. Megmértük a képalkotáshoz és a beállítási hiba meghatározásához szükséges időket. Az összehasonlítást normalitásvizsgálat és F-próbát követően kétmintás T-próbával végeztük ( $<<0,05$ szinten). Szakirodalmi adatok alapján becsültük a képalkotási dózisokat is.

\section{Eredmények}

A $66 \mathrm{MV}-\mathrm{kV}$ felvételt számítógépes csontalapú képregisztrációval illesztettük a tervezéses CT-sorozatból generált digitálisan rekonstruált röntgenképekhez (DRR) (1. ábra). Törekedtünk a cervicalis gerincszakasz pontos illesztésére. A 66 CBCT-felvételt a tervezéses CT-vel közvetlenül tudtuk összeilleszteni (2. ábra). A háromdimenziós képi információt felhasználva ez esetben is a nyaki gerinc pontos illeszkedését céloztuk. A regisztrációk elvégzését követôen kiolvastuk a vertikális (VRT), a longitudinális (LNG) és a laterális (LAT) transzlációs irányokban mért, aznapi beállítási hiba mértékét. Eredményeinket az 1. táblázat tartalmazza. Az átlagos VRThiba MV-kV alapján 0,5 mm $(S D=1,9)$, CBCT alapján ugyan kevesebb, 0,4 $\mathrm{mm}(\mathrm{SD}=2,1)$, de a különbség nem mutatkozott szignifikánsnak $(\mathrm{p}=0,371)$. A LNGhiba átlaga $\mathrm{MV}$-kV-nél $0,2 \mathrm{~mm}(\mathrm{SD}=2,2)$, CBCT-nél $-0,1 \mathrm{~mm}(\mathrm{SD}=2,2)$. A különbség itt sem volt szignifikáns $(\mathrm{p}=0,188)$. Hasonló eredményre vezetett a LAThibák elemzése, $M V-k V$-nél átlagosan $0,2 \mathrm{~mm}(\mathrm{SD}=$ 2,2), CBCT-nél átlagosan $0,3 \mathrm{~mm}(\mathrm{SD}=2,1), \mathrm{p}=0,41$. A Van Herk-képlet alapján kiszámított, szükséges biztonsági margók MV-kV képek alapján: VRT: 2,7 mm, LNG: $2,1 \mathrm{~mm}$, LAT: $2,2 \mathrm{~mm}$; CBCT alapján: VRT: 2,5 mm, LNG: 1,3 mm, LAT: 2,3 mm. A képalkotáshoz szükséges időket átlagosan 0,65 percnek $(\mathrm{MV}-\mathrm{kV})$ és
1. táblázat | Hibák, margó, idők, dózisok

\begin{tabular}{|c|c|c|c|c|}
\hline & & $M V-k V$ & CBCT & $\mathrm{p}$ \\
\hline \multirow[t]{3}{*}{ SE } & VRT & $0,5 \mathrm{~mm}(\mathrm{SD} 1,9)$ & $0,4 \mathrm{~mm}(\mathrm{SD} 2,1)$ & 0,371 \\
\hline & LNG & $0,2 \mathrm{~mm}(\mathrm{SD} 2,2)$ & $-0,1 \mathrm{~mm}(\mathrm{SD} 2,2)$ & 0,188 \\
\hline & LAT & $0,2 \mathrm{~mm}(\mathrm{SD} 2,2)$ & $0,3 \mathrm{~mm}(\mathrm{SD} 2,1)$ & 0,41 \\
\hline \multirow[t]{3}{*}{ SM } & VRT & $2,7 \mathrm{~mm}$ & $2,5 \mathrm{~mm}$ & \\
\hline & LNG & $2,1 \mathrm{~mm}$ & $1,3 \mathrm{~mm}$ & \\
\hline & LAT & $2,2 \mathrm{~mm}$ & $2,3 \mathrm{~mm}$ & \\
\hline \multicolumn{2}{|l|}{ IT } & 0,65 perc & 2,29 perc & \\
\hline \multicolumn{2}{|l|}{ ET } & 2,41 perc & 2,41 perc & \\
\hline \multicolumn{2}{|l|}{ ID } & $6,88 \mathrm{mGy}$ & $17,2 \mathrm{mGy}$ & \\
\hline
\end{tabular}

$\mathrm{ET}=($ evaluation time $)$ kiértékelési idő; ID = (imaging dose $)$ képalkotási dózis; IT = (imaging time) képalkotási idő; $\mathrm{SE}=$ (setup error) beállítási hiba; $S M=($ setup margin $)$ biztonsági margó

2,29 percnek (CBCT) mértük. A beállítási hiba meghatározásához szükséges idő mindkét képalkotó esetében átlagosan 2,41 perc volt. A szakirodalmi adatok alapján becsült képalkotási dózisok frakciónként és betegenként 6,88 mGy (MV-kV), illetve 17,2 mGy (CBCT) voltak.

\section{Megbeszélés}

Magyarországon 2001 és 2014 között a rosszindulatú daganatos megbetegedések 6,5-5,1\%-át fej-nyaki lokalizációban diagnosztizálták [1]. Bár ez az arány az évek múlásával javuló tendenciát mutatott (3. ábra), a százezer före vetített fej-nyak tumorok száma nem változott jelentősen, 48 és 52 között ingadozott (4. ábra). Az öszszes rákos megbetegedés abszolút száma és a százezer lakosra jutó új esetek száma is emelkedő tendenciát mutatott (5. és 6. ábra). A fej-nyaki régióban az esetszám stagnált (7. ábra). Az előfordulási arány javulása tehát látszólagos volt, nem fej-nyak rákból lett kevesebb, hanem az egyéb lokalizációjú daganatok száma emelkedett. Fontos kérdés tehát e betegcsoport kezelési módszereinek vizsgálata, mely a jelen közleményben tárgyalt sugárterápián - annak is egy speciális kérdéskörén - túl a

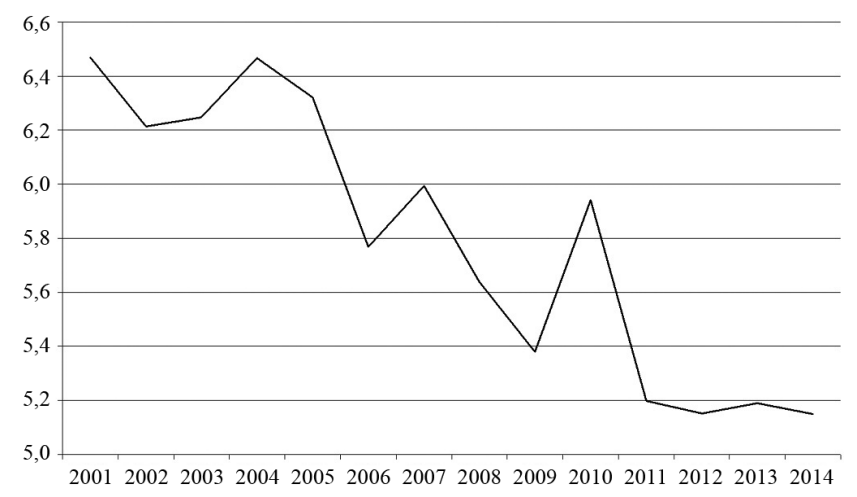

3. ábra $\mid$ Fej-nyaki daganatok \%-os aránya az összes daganatos megbetegedéshez képest 

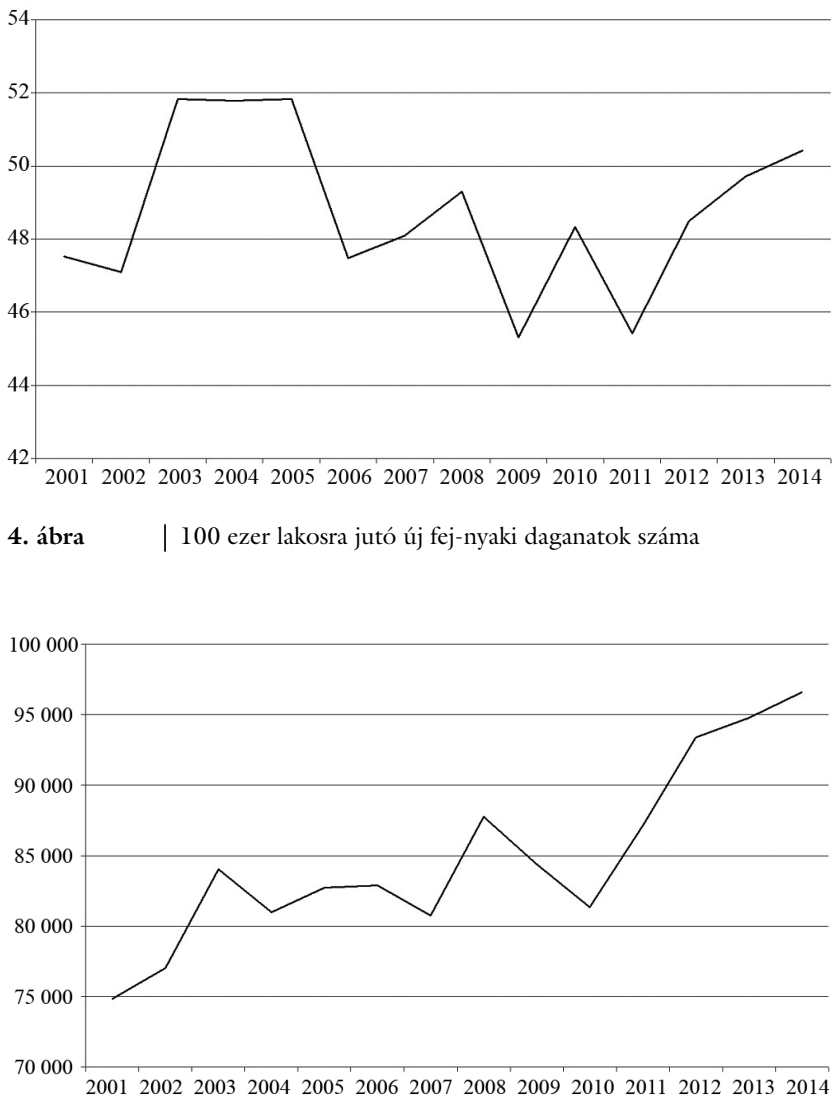

5. ábra | Új daganatos megbetegedések száma

sebészeti és a gyógyszeres lehetőségeket is magában foglalja.

A hazai szakirodalomban a sebészi kezelésre vonatkozó megfontolásokat közlő Háromi és mtsai megállapították, hogy a mútéti technika megválasztása szignifikáns hatással van az onkológiai eredményre [9]. Nagy és mtsai a mútétet követő rehabilitáció kapcsán vizsgálódtak, és megállapították, hogy a fej-nyaki daganat miatt operált betegek életminősége javításának eredményességét jelentôsen befolyásolja a betegek dohányzási szokása [10].

A kemoterápia és a radiokemoterápia témakörében is számos hazai és nemzetközi közlemény született, melyek a kemoterápiás szerek hatását, kombinációjuk hatékonyságát, a daganatok sugárérzékenyítésének lehetőségét és a normálszövetek sugárérzékenységének csökkentését is vizsgálták [11-14].

A sebészi és a gyógyszeres kezelés mellett a komplex onkológiai ellátás szerves része a sugárterápia. Magyarországon minden sugárterápiás központ rendelkezik a korszerú, úgynevezett intenzitásmodulált sugárkezeléses (IMRT-) és/vagy intenzitásmodult ívterápiás (VMAT-) ellátáshoz szükséges technológiákkal, melyek a fej-nyaki régióban ma már kizárólagos standardnak nevezhetók. Pesznyák és mtsai összehasonlító dozimetriai elemzést végeztek hagyományos konformális és IMRT-besugárzási tervek között [15]. Az intenzitásmodulált tervek lehetővé teszik a tervezéses céltérfogat (PTV) magas konfor-

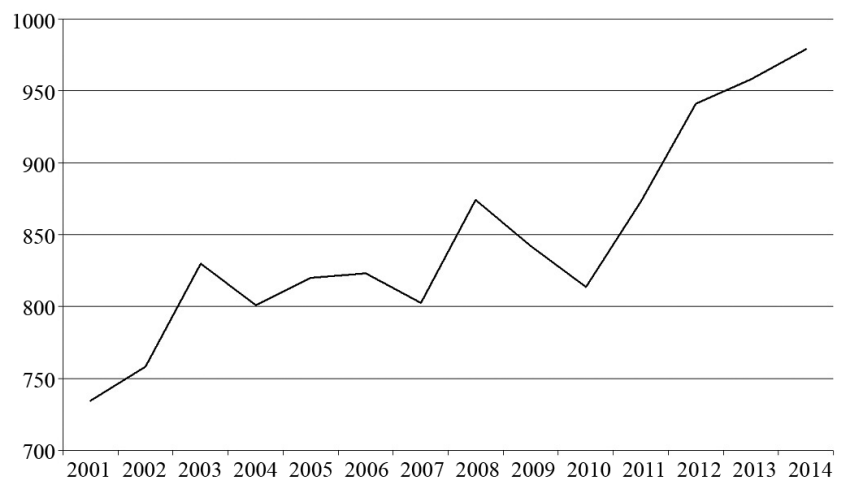

6. ábra $\mid 100$ ezer lakosra jutó új daganatos megbetegedések száma

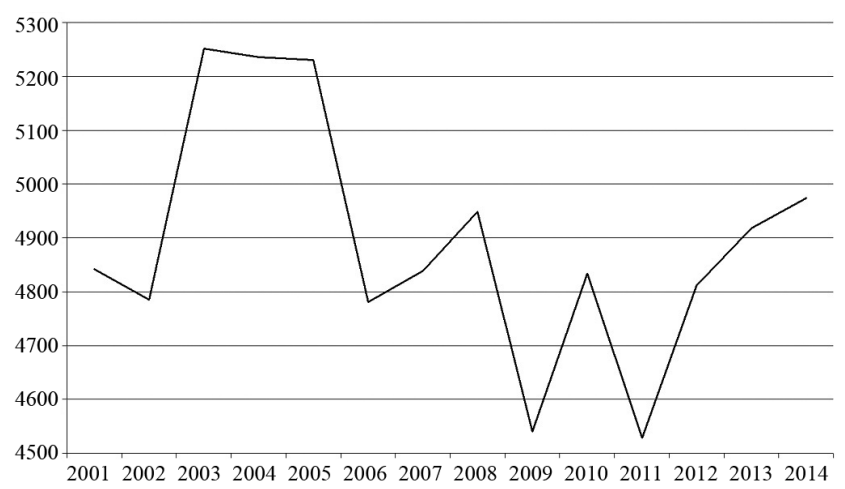

7. ábra | Új fej-nyaki daganatos megbetegedések száma

mitású, és magas dózishomogenitású besugárzását amellett, hogy biztosítják a védendő szervek toleranciadózisainak betartását. A képvezérelt sugárterápia (IGRT) technikáinak alkalmazása az IMRT- és VMAT-besugárzások pontos és biztonságos kivitelezésének szükséges feltétele. Fő feladata a beteg pontos pozicionálásának javítása és a céltérfogat meghatározásakor alkalmazott beállítási biztonsági margó (SM) csökkentésének megalapozása. A fej-nyaki daganatos betegek esetén ez a gyakorlatban történhet kétdimenziós ortogonális röntgenfelvételpárral (MV-kV) vagy cone-beam CT-vel (CBCT) végzett felvételezés alapján [6].

A biztonsági margók meghatározása során számos tényező́t figyelembe kell venni. Számolni kell a belső szervek mozgásával, mely a klinikai céltérfogat (CTV) helyzetének megváltozását eredményezi. A kontúrozás során ezért szervmozgási biztonsági margót kell alkalmazni (IM) (8. és 9. ábra). A sugárkezelés ideje alatt a beteget a kezelés minden napján pozicionálni kell a kezelőasztalon ugyanabban a helyzetben, amelyben a tervezéses CT-felvétel elkészítése során feküdt. A fektetési helyzet reprodukálhatóságát fej-nyaki daganatos betegek esetén megkönnyíti a fejrögzító párna és a hőre lágyuló termoplasztikus maszk alkalmazása, de napi beállítási hibával nagy valószínúséggel ekkor is számolnunk kell, alkalmaznunk kell beállítási biztonsági margót $(S M)$ is. Az IM és az SM is csak a tumor környezetében lévő ép szövetek 

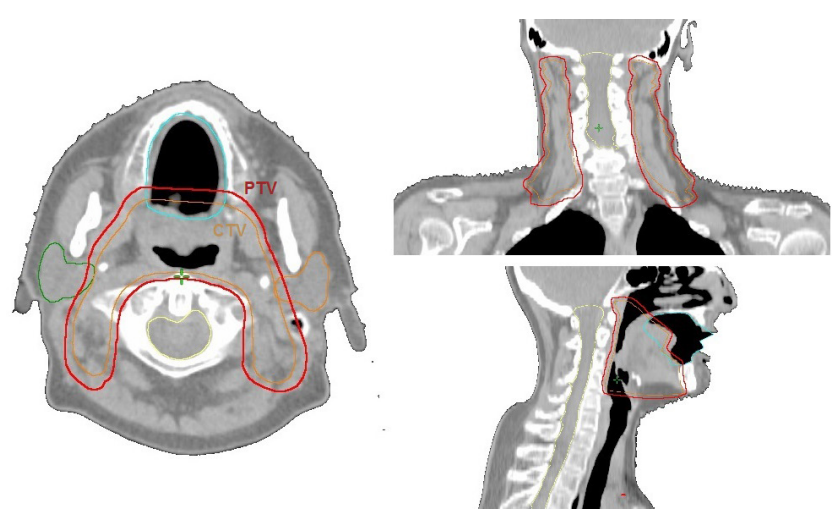

8. ábra

| CTV-és PTV-kontúrok

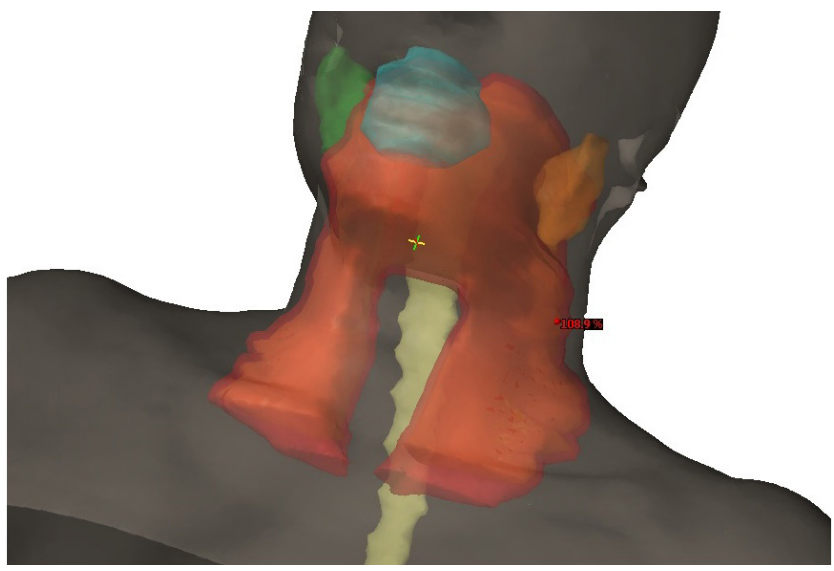

9. ábra

| Céltérfogatok térbeli rekonstrukciója

kárára terjeszthető ki. Ezért törekedni kell az alkalmazott margók méretének észszerü csökkentésére. Az SM csökkentésében segítenek az IGRT-technikák. A napi beállítási hibák átlaga adja a szisztematikus hibát $(\Sigma)$, szórása pedig a véletlenszerü hibát $(\sigma)(10$ ábra) [6].

Van Herk és mtsai javaslatot fogalmaztak meg, melynek alapján a kontúrozáskor alkalmazandó SM mértékét a szisztematikus és a véletlenszerü hibák méréssel történő megállapítását követően az alábbi képlettel ajánlott kiszámítani [8].

$$
\mathrm{SM}=2,5 \Sigma+0,7 \sigma
$$

Hong és mtsai 2006-ban vizsgálták a napi beállítási hibák IMRT-kezelésre gyakorolt hatását. Esetükben a konvencionális fej-nyak maszkolás és lézerjelölés segítségével végzett napi pozicionálást használva, az átlagos beállítási hiba egyetlen dimenzióban átlagosan $3,33 \mathrm{~mm}$ volt. Arra a következtetésre jutottak, hogy a fej-nyak IMRT sikeres végrehajtása megköveteli a pontos és reprodukálható tervezést, továbbá a napi beállítási hibák káros hatásai korántsem elhanyagolhatók, s még a konvencionális fejnyak maszkolás nagy jelentőséggel bírhat e tekintetben [16]. A termoplasztikus maszk használata intézetünkben is bevett rutin, beállítási hibáink is hasonlóak az említett tanulmányban közöltekhez.

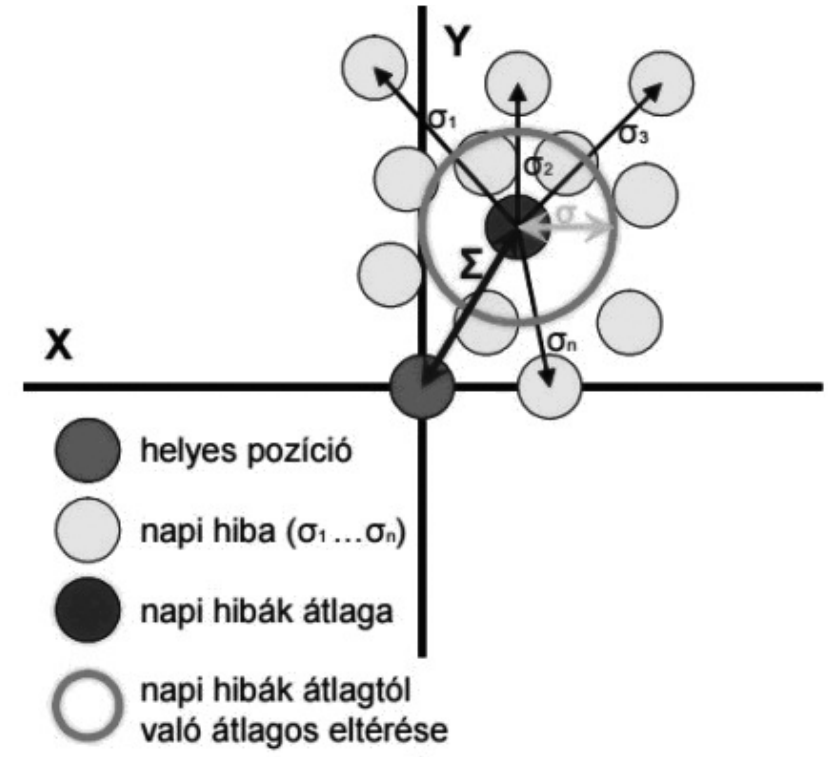

10. ábra Szisztematikus és véletlenszerú beállítási hibák

Li és mtsai 2008-as vizsgálata megállapította, hogy ortogonális felvételpár és CBCT alkalmazásával is $\mathbf{3}-\mathbf{5 m}$ nél kisebb napi beállítási hibákat lehet felfedezni. A két technológia közötti fó különbséget a fej-nyaki struktúrák flexibilitása és esetleges rotációja adja, melyet a CBCT-n pontosabban fel lehet mérni, mint az ortogonális vetületi képeken. A beállítási hibák további csökkentése céljából javasolják e rotációs hibák kiküszöbölését célzó rögzítési eljárások alkalmazását [17]. Az alkalmazott technika hibamérési hatékonyságát tekintve mi sem találtunk jelentős különbséget. Egyetértünk azonban azzal, hogy a rotációs hibák és a lágyszöveti eltérések a háromdimenziós CBCT-n valóban könnyebben azonosíthatók, mint a $\mathrm{MV}-\mathrm{kV}$ felvételpáron.

Hawkins és mtsai, valamint Martins és mtsai 2011ben, illetve 2016-ban nyelőcsőtumorok esetén vizsgálták a két képalkotó eljárás hatékonyságának esetleges különbségét. Az előbbi szerzők nem találtak szignifikáns különbséget a két modalitás által szolgáltatott információk alapján számított SM-ekben, de kiemelték a CBCT előnyét a lágy részek pontos megítélésében [18]. A második csoport ugyanígy tekinti elődlegesnek a CBCT-t, ők a beállítási margókban szignifikáns különbségre is jutottak. Ennek oka abban állhat, hogy míg a vetületi képeken csak csontalapú képregisztráció használható, addig a CBCT-t a lágyszöveti képletek figyelembevételével illesztették [19]. Bár ezek a vizsgálatok nem fej-nyaki régióban történtek, a megfogalmazott következtetésekkel egybevágó tapasztalatról számolnak be.

Zhao és mtsai 2016-ban hasonló összehasonlítást végeztek, a fentiekkel egybevágó megállapítással, miszerint az ortogonális felvételpár és a CBCT nem mutat szignifikánsan különböző beállítási hibákat [20]. A mi eredményeinkhez hasonlóan megállapították azonban, hogy a felvételkészítéshez szükséges idő szignifikánsan rövidebb 
a felvételpár esetén, ami e technológiának az előnyei közé sorolandó.

Di Biase és mtsai 2016-ban CBCT-felvételezéssel vizsgálták a fej-nyak tumoros betegek transzlációs és rotációs beállítási hibáit. Transzlációban az általunk megfigyelthez hasonló eredményre jutottak, minden irányban 1,5$2 \mathrm{~mm}$-es átlagos eltérést találtak. A rotációs hibák átlagát 0,3-0,6-nak mérték a három forgási tengely körül. Megállapítható, hogy a CBCT az ilyen kis mértékű elfordulás detektálására is alkalmas [21].

Ding és mtsai 2011-ben az egyes képalkotó technológiák által a felvételezés során adott többletdózist mérték meg. Arra a következtetésre jutottak, hogy a MV-os felvétel jelentősen nagyobb dózissal jár, mint a $\mathrm{kV}$-felvételezés vagy a CBCT [22]. Walter és mtsai 2007-ben szintén magasabbnak találták a MV-os felvétel dózisát, mint a $\mathrm{kV}$-os felvételét és a CBCT-ét. Ez utóbbi csoport azonban beszámol arról, hogy a MV-os felvételhez $5 \mathrm{MU}$ besugárzást használtak, így 30-60 mGy többletdózist mértek [23]. A jelenlegi EPID-eszközökkel már 1 MU-val is jó minőségű kép készíthető, amely már csak 6-10 mGy dózist jelent. Ez már alacsonyabb, mint a CBCT-nél mért 10-17,2 mGy, viszont továbbra is jelentősen meghaladja a $\mathrm{kV}$-os felvétel 0,1-0,2 mGy dózisát.

\section{Következtetés}

A felvételek elkészítése, a napi beállítási hibák megállapítása és az alkalmazandó SM kiszámítása után arra jutottunk, hogy a fej-nyak daganatos betegek esetén csontalapú képregisztrációt használva a MV-kV-és a CBCT-alapú felvételezés nem vezet szignifikánsan különböző eredményre. A képalkotási idő MV-kV esetén jelentősen rövidebb, mint CBCT-nél. Rossz általános állapotú beteg esetén az így elérhető időnyereség hasznos lehet, figyelembe véve a maszkrögzítés és a betegtől elvárt mozdulatlan fekvés kényelmetlenségét. A képalkotási dózisok becslése szintén a MV-kV mellett szól, ám figyelembe véve, hogy a CBCT 10-17 mGy dózisa is csak 1\%-a a napi általános terápiás 1,8-2 Gy frakciódózisnak, a MVkV-vel elérhető dóziscsökkentésnek véleményünk szerint nincs klinikai jelentősége. A CBCT viszont klinikailag releváns előnnyel jár, ha a rotációs hibák korrigálását is el kívánjuk végezni. A beteg craniocaudalis tengelye körüli elfordulását csak 3D képi információ alapján lehet meghatározni, ez a MV-kV képpáron elméletileg sem lehetséges. A CBCT további fontos előnye, hogy lehetőséget biztosít a lágyszöveti változások nyomon követésére is. Használatával kimutatható a kezelés közben bekövetkező esetleges makroszkopikus regresszió, mely a besugárzási terv módosításának indikációját is felvetheti.

Arra a következtetésre jutottunk, hogy fej-nyak tumoros betegek IGRT-alapú IMRT/VMAT sugárkezelésekor elsődlegesen javasolt a CBCT mint háromdimenziós képalkotó modalitás használata.
A MV-kV ortogonális felvételpár abban az esetben elfogadható alternatíva, ha a beteg általános állapota szükségessé teszi a képalkotási idő rövidítését.

Anyagi támogatás: A közlemény megírása, illetve a kapcsolódó kutatómunka anyagi támogatásban nem részesült.

Szerzôi munkamegosztás: K. P.: A kutatás vezetője, a közlemény szerkesztője. Sz. E.: Beállítási hibák mérése, statisztikai értékelés. S. K., K. Sz.: Beállítási hibák mérése, adatfeldolgozás. K. J.: A képregisztráció pontosságának ellenőrzése. K. Á., R. I., H. J.: A kutatás szakmai és etikai felügyelete, a szükséges eszközök biztosítása. A közlemény végleges változatát valamennyi szerző elolvasta és jóváhagyta.

Érdekeltségek: A szerzőknek nincsenek érdekeltségeik.

\section{Irodalom}

[1] http://www.onkol.hu/hu/rakregiszter-statisztika

[2] Schlumpf M, Fischer C, Naehrig D, et al. Results of concurrent radio-chemotherapy for the treatment of head and neck squamous cell carcinoma in everyday clinical practice with special reference to early mortality. BMC Cancer 2013; 13: 610.

[3] Bücheler BM, Ehnes A, Kavsadze M, et al. Quality of life after treatment of head and neck tumors: longitudinal comparison after operation and adjuvant radio(chemo)therapy. HNO 2012; 60: 1053-1059.

[4] Fakhrian K, Thamm R, Knapp S, et al. Radio(chemo)therapy in the management of squamous cell carcinoma of cervical lymph nodes from an unknown primary site. A retrospective analysis. Strahlenther Onkol. 2012; 188: 56-61.

[5] Hideghéty K, Cserháti A, Besenyi Z, et al. Role of 18FDG-PET/ $\mathrm{CT}$ in the management and gross tumor volume definition for radiotherapy of head and neck cancer; single institution experiences based on long-term follow-up. [18FDG-PET/CT szerepe fej-nyak daganatok kezelésében és a sugárterápiás tumortérfogat meghatározásában - Az SZTE Onkoterápiás Klinika eredményeinek értékelése.] Magy Onkol. 2015; 59: 103-110. [Hungarian]

[6] Kovács P, Sebestyén Zs, Farkas R, et al. Forms and application of image guided radiation theraphy. [A képvezérelt sugárterápia formái és alkalmazása.] Egészség Akadémia 2010; 1: 313-322. [Hungarian]

[7] Rooney KP, Miah AB, Bhide SA, et al. Intensity modulated radiotherapy in locally advanced thyroid cancer: Outcomes of a sequential phase I dose-escalation study. Radiother Oncol. 2018; 127: 43-48.

[8] van Herk M, Remeijer P, Rasch C, et al. The probability of correct target dosage: dose-population histograms for deriving treatment margins in radiotherapy. Int J Radiat Oncol Biol Phys. 2000; 47: 1121-1135.

[9] Háromi I, Gerlinger I, Lujber L, et al. Maximizing nodal yield while minimizing surgical morbidity: the appropriate neck dissection. [A nyaki dissectiók onkológiai hozamának maximalizálása a sebészi morbiditás egyidejű minimalizálása mellett.] Orv Hetil. 2016; 157: 1871-1879. [Hungarian]

[10] Nagy J, Novák P, Buzás K, et al. The effect of smoking on the quality of life enhancement following prosthetic rehabilitation in head and neck cancer patients who underwent surgical treatment. [A dohányzás hatása a fej-nyak régió daganata miatt sebészi terápiában részesült betegek protetikai rehabilitációt követő 
életminőség-javulására.] Orv Hetil. 2017; 158: 172-177. [Hungarian]

[11] Ruzsa A, Sen M, Evans M, et al. Phase 2, open-label, 1:1 randomized controlled trial exploring the efficacy of EMD 1201081 in combination with cetuximab in second-line cetuximab-naïve patients with recurrent or metastatic squamous cell carcinoma of the head and neck (R/M SCCHN). Invest New Drugs 2014; 32: 1278-1284.

[12] Koltai P, Remenár É, Boér A, et al. Neoadjuvant chemotherapy in head and neck cancer. [Neoadjuváns kemoterápia fej-nyaki laphámrákban.] Magy Onkol. 2001; 45: 197-199. [Hungarian]

[13] Lövey J, Koronczay K, Remenár É, et al. Low-dose Taxol radiosensitization in locally advanced head and neck cancers. [Alacsony dózisú Taxol-sugárérzékenyítés helyileg előrehaladott fejnyaki daganatokban]. Magy Onkol. 2001; 45: 201-206. [Hungarian]

[14] Patyánik M, Mayer Á, Póti Zs. Radio-chemotherapy of locally advanced head and neck cancer, providing tissue and organ protection. [Előrehaladott fej-nyaki tumorok radio-kemoterápiája szöveti-szervi védelem mellett. Korai eredmények.] Magy Onkol. 2001; 45: 327-330

[15] Pesznyák Cs, Béla D, Takácsi-Nagy Z, et al. Dosimetry analysis of intensity-modulated and conformal radiation therapy for head and neck tumors. [Intenzitásmodulált és konformális besugárzási tervek dozimetriai elemzése fej-nyak tumorok külső besugárzásánál.] Magy Onkol. 2015; 59: 95-101. [Hungarian]

[16] Hong TS, Tomé WA, Chappell RJ, et al. The impact of daily setup variations on head-and-neck intensity-modulated radiation therapy. Int J Radiat Oncol Biol Phys. 2006; 61: 779-788.

[17] Li H, Zhu XR, Zhang L, et al. Comparison of 2D radiographic images and $3 \mathrm{D}$ cone-beam computed tomography for position- ing head and neck radiotherapy patients. Int J Radiat Oncol Biol Phys. 2008; 71: 916-925.

[18] Hawkins MA, Aitken A, Hansen VN, et al. Set-up errors in radiotherapy for oesophageal cancers - Is electronic portal imaging or conebeam more accurate? Radiother Oncol. 2011; 98: 249254.

[19] Martins L, Couto JG, Barbosa B. Use of planar kV vs. CBCT in evaluation of setup errors in oesophagus carcinoma radiotherapy. Rep Pract Oncol Radiother. 2016; 21: 57-62.

[20] Zhao LR, Zhou YB, Li GH, et al. The clinical feasibility and performance of an orthogonal X-ray imaging system for imageguided radiotherapy in nasopharyngeal cancer patients: Comparison with cone-beam CT. Phys Med. 2016; 32: 266-271.

[21] Di Biase M, Trignani M, Caponigro G, et al. Translational and rotational set-up uncertainties in head and neck cancer treatments using CBCT. Radiother Oncol. 2016; 119(Suppl 1): S835-S836.

[22] Ding GX, Munro P. Comparing MV and kV imaging doses for image guided radiation therapy. Int J Radiat Oncol Biol Phys. 2011; 81(Suppl): S771-S772.

[23] Walter C, Boda-Heggemann J, Wertz H, et al. Phantom and invivo measurements of dose exposure by image-guided radiotherapy (IGRT): MV portal images vs. $\mathrm{kV}$ portal images vs. conebeam CT. Radiother Oncol. 2007; 85: 418-423.

(Kovács Árpád dr., Kaposvár, Szent Imre u. 14/B, 7400 e-mail: arpad.kovacs@etk.pte.hu)

\section{NOTA \\ Új fejlesztés az egészségügyben dolgozók, tanulók részére!}

\section{A magyar nyelvứ szakirodalmi keresőszolgáltatás}

Mi a NOTA?
Napivizit Orvosi Tudástár Alkalmazás
Mit tud a NOTA portál?
Megkönnyíti a magyar nyelvü
szakirodalmi források keresését.
Eszköztöl függetlenül, akár
okostelefonról, a betegágy mellett
állva is használható.

Miben kereshet a NOTA-val?

Az Akadémiai Kiadó folyóirataiban: Orvosi Hetilap, Magyar Sebészet, Mentálhigiéné és Pszichoszomatika.

Más kiadók magyar nyelvủ szakfolyóirataiban: pl. Lege Artis Medicinae, Hypertonia és Nephrologia, Ideggyógyászati Szemle.

Magyar nyelvű kérdésekre adott ango nyelvű találatokban, a PubMeden.

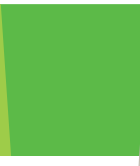

\section{nota.hu}

Amennyiben további információra lenne szüksége, keressen minket elérhetőségeinken:

journals@akademiai.hu /hirdetes@akademiai.hu
A hatályos szakmai irányelvekben.

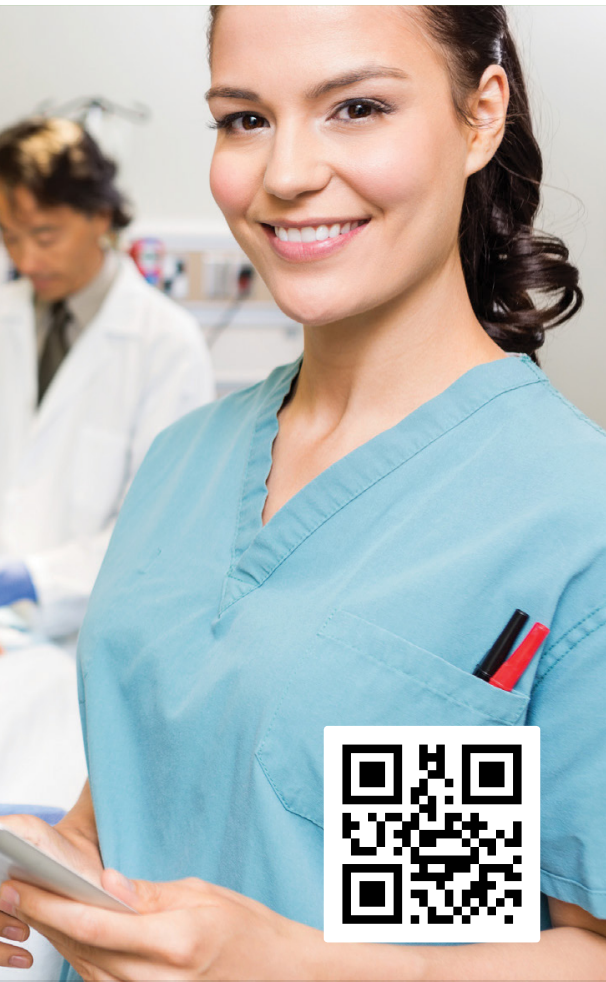

\section{Akadémiai Kiadó}

A Wolters Kluwer Csoport tagja

1117 Budapest, Prielle Kornélia u. 21-35. / Telefon: (1) 464-8246 www.akademiai.hu / www.akademiai.com

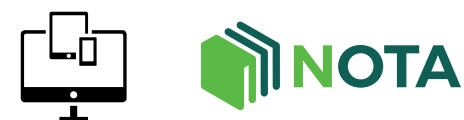

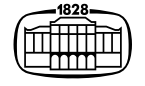

AKADÉMIAI KIADÓ 